\title{
SOCIAL CLASS DISTRIBUTION OF RESPIRATORY TUBERCULOSIS MORTALITY IN NORTHERN IRELAND, 1949-53
}

\author{
BY
}

\author{
J. D. MERRETT
}

Department of Social and Preventive Medicine, Queen's University, Belfast

The occupational and social class distribution of mortality in Northern Ireland has not been previously studied, because suitable data have only recently become available. The Registrar General for Northern Ireland (1955) included, for the first time in a census report, the age and social class distribution of the adult male population in 1951. As no official analysis of mortality by social class is contemplated, this paper presents the social class distribution of respiratory tuberculosis mortality for males, using the published population data and the death registrations for 1949-53 made available through the courtesy of the Registrar General for Northern Ireland. The analysis is limited to male mortality, because no population data for married women classified by husband's occupation has yet been published.

\section{MATERIAL}

The classification procedures and methods of presenting the data follow closely those used by the General Register Office (1956) and the Registrar General for England and Wales $(1958 a, b)$ so that comparison between the two countries can be made.

In Northern Ireland in 1949-53 there were 1,254 deaths of males aged 15 years and over which were attributed to respiratory tuberculosis. Of the men who died, 1,198 (95.5 per cent.) were classified as "occupied or retired", including the active, out of work, and retired. The remaining $56(4 \cdot 5$ per cent.) were classified as "unoccupied"; this group is thus exclusive of the retired and out of work. These terms are used in the same sense as in the official reports for England and Wales (e.g. Registrar General for England and Wales, 1958a). As the "unoccupied" group contains only a small number of registered deaths from respiratory tuberculosis, this group has been omitted throughout this report. Classification of the relevant death certificates as in England and
Wales (General Register Office, 1956), according to occupation last followed by the deceased and then by social class, showed that there were twenty deaths in Social Class I (Professional), 156 in Class II ("Intermediate"), 502 in Class III (Skilled), 117 in Class IV (Partly skilled) and 403 in Class V (Unskilled).

\section{Results}

Table I shows the conventional standardized mortality ratios (S.M.R.s) for all ages from 15 years and over. The large standard error for Social Class I raises doubts whether, in fact, mortality in this class is heavier than in Social Class II; consequently the Table also shows the S.M.R. for these two classes combined. The S.M.R. in Social Class V was about twice as great as in Social Class III, and that in Social Class III about twice as great as that in Social Classes I and II combined. The S.M.R. for Social Class IV is very much lower than would be expected from the mortality gradient implied by the remaining social classes, being, in fact, similar to that of the highest Social Classes I and II combined.

TABLE I

RESPIRATORY TUBERCULOSIS MORTALITY AMONG MALES AGED 15 YEARS AND OVER IN NORTHERN IRELAND (1949-53)

REGISTERED AND EXPECTED DEATHS BY SOCIAL CLASS

\begin{tabular}{|c|c|c|c|c|}
\hline \multicolumn{2}{|l|}{ Social Class } & Registered & Expected & S.M.R. \pm S.E.* \\
\hline $\begin{array}{l}\text { I (Professional) } \\
\text { II (Intermediate) }\end{array}$ & $\ddot{*}$ & $\begin{array}{r}20 \\
156\end{array}$ & $\begin{array}{r}31 \cdot 62 \\
316 \cdot 44\end{array}$ & $\begin{array}{l}63 \pm 14 \cdot 1 \\
49 \pm 3 \cdot 9\end{array}$ \\
\hline $\begin{array}{l}\text { I and II Combined } \\
\text { III (Skilled) } \\
\text { IV (Partly Skilled) } \\
\text { V (Unskilled) }\end{array}$ & $\begin{array}{l}\cdots \\
\cdots \\
\cdots\end{array}$ & $\begin{array}{l}176 \\
502 \\
117 \\
403\end{array}$ & $\begin{array}{l}348 \cdot 06 \\
447 \cdot 85 \\
230 \cdot 85 \\
198 \cdot 60\end{array}$ & $\begin{array}{r}51 \pm 3 \cdot 8 \\
112 \pm 5 \cdot 0 \\
51 \pm 4 \cdot 7 \\
203 \pm 10 \cdot 1\end{array}$ \\
\hline Unoccupied & $\ldots$ & 56 & $28 \cdot 64$ & $196 \pm 26 \cdot 1$ \\
\hline All Males & $\ldots$ & 1,254 & 1,254 & 100 \\
\hline
\end{tabular}

- Standardized mortality ratio \pm standard error 
S.M.R.s, though convenient in this context, can be misleading as indices of the variations in mortality which might occur between the social classes at particular ages. Therefore in Table II the age specific rates are shown. Unfortunately the total male population concerned $(474,209)$ is small, so that at some ages the rates are based on small numbers and must be interpreted with caution. If attention is confined to the rates for Social Classes I and II combined, III, IV, and V, certain constant factors nevertheless emerge (Table II). Thus, at each age group, except 15 to 19 years, Social Class V has the highest rate and, except at 65-69 years, Social Class III has the next highest rate. Social Classes I and II combined have the lowest rate in five age groups and Social Class IV the lowest rate in three. The rates for Social Classes I and II combined and for Social Class IV are very similar in each age group (Table

\section{TABLE II}

RESPIRATORY TUBERCULOSIS MORTALITY AMONG MALES IN NORTHERN IRELAND (1949-53) BY AGE AND SOCIAL CLASS

AVERAGE ANNUAL NUMBER OF DEATHS PER 100,000 OF THE POPULATION AT STATED AGE GROUP IN YEARS

\begin{tabular}{c|c|c|c|c}
\hline \multirow{2}{*}{ Age Group (yrs) } & \multicolumn{4}{|c|}{ Social Class } \\
\cline { 2 - 5 } & I and II & III & IV & V \\
\hline $15-19$ & $(31)$ & $(10)$ & $(3)$ & $(24)$ \\
$20-24$ & $(13)$ & 22 & $(15)$ & 65 \\
$25-34$ & $(23)$ & 49 & 27 & 79 \\
$35-44$ & 31 & 52 & $(20)$ & 115 \\
$45-54$ & 39 & 91 & 40 & 150 \\
$55-64$ & 33 & 139 & 32 & 192 \\
$65-69$ & 52 & $(56)$ & $(64)$ & 174 \\
$70+$ & 25 & 58 & $(36)$ & 90 \\
\hline
\end{tabular}

Note: In this and subsequent Tables the rates in brackets are based on less than twenty deaths.
II), as suggested by the S.M.R.s for these groups (Table I). In general the rates are more divergent between social class at the higher than at the lower ages.

To facilitate comparison with data for England and Wales, the S.M.R.s for Northern Ireland have been restricted to age 20-64 years; this limitation makes no material difference to the gradient or to the exception observed in Table I from the S.M.R.S based on ages 15 and over. Table III shows the S.M.R.s for the two countries by social class. In England and Wales the S.M.R.s for Social Classes III and IV are very similar (102 and 95 per cent. respectively) and, moreover, as is seen in Table IV, at each age group, the average annual age specific rates for these two social classes are also similar. Thus, in England and Wales, mortality differences due to respiratory tuberculosis appear to have been negligible between Social Classes III and IV. In England and Wales, Social Classes I and II combined have the lowest, while Social Class V has the highest rate in each age group, and the range of the rates is greatest at the older ages (Table IV). Thus the relative rankings of the social classes are not inconsistent with that already noted for Northern Ireland; except that Social Class IV in England and Wales has a similar mortality experience to Social Class III, whereas in Northern Ireland the experience of Social Class IV resembles that of Social Classes I and II combined.

The S.M.R.s (Table III) for Social Classes I and II combined are 48 per cent. for Northern Ireland and 62 per cent. for England and Wales, indicating that mortality in these classes in England and Wales was nearer to the average mortality of that country, after allowance for age, than was the mortality in these

TABLE III

RESPIRATORY TUBERCULOSIS MORTALITY AMONG MALES AGED 20-64 YEARS IN NORTHERN IRELAND AND ENGLAND AND WALES (1949-53)

REGISTERED AND EXPECTED DEATHS BY SOCIAL CLASS

\begin{tabular}{|c|c|c|c|c|c|c|}
\hline \multirow{2}{*}{ Social Class } & \multicolumn{3}{|c|}{ Northern Ireland } & \multicolumn{3}{|c|}{ England and Wales } \\
\hline & $\begin{array}{l}\text { Registered } \\
\text { Deaths }\end{array}$ & $\begin{array}{l}\text { Expected } \\
\text { Deaths }\end{array}$ & S.M.R. \pm S.E. & $\begin{array}{l}\text { Registered } \\
\text { Deaths }\end{array}$ & $\begin{array}{c}\text { Expected } \\
\text { Deaths }\end{array}$ & S.M.R. \pm S.E. \\
\hline$\underset{\text { III }}{\text { II }}$ & $\begin{array}{r}15 \\
116 \\
446 \\
91 \\
345\end{array}$ & $\begin{array}{r}27 \cdot 17 \\
246 \cdot 66 \\
388 \cdot 44 \\
192 \cdot 89 \\
170 \cdot 36\end{array}$ & $\begin{array}{r}55 \pm 14 \cdot 3 \\
47 \pm 4.4 \\
115 \pm 5 \cdot 4 \\
47 \pm 4.9 \\
203 \pm 10.9\end{array}$ & $\begin{array}{r}619 \\
3,129 \\
15,722 \\
4,687 \\
6,136\end{array}$ & $\begin{array}{r}1,060 \\
4,992 \\
15,465 \\
4,945 \\
4,302\end{array}$ & $\begin{array}{r}58 \pm 2.3 \\
63 \pm 1.1 \\
102 \pm 0.8 \\
95 \pm 1.4 \\
143 \pm 1.8\end{array}$ \\
\hline $\begin{array}{l}\text { II and II } \\
\text { IV and V }\end{array}$ & $\begin{array}{l}131 \\
446 \\
436\end{array}$ & $\begin{array}{l}273 \cdot 83 \\
388 \cdot 44 \\
363 \cdot 25\end{array}$ & $\begin{array}{l}48 \pm 4 \cdot 2 \\
115 \pm 5 \cdot 4 \\
120 \pm 5 \cdot 7\end{array}$ & $\begin{array}{r}3,748 \\
15,722 \\
10,823\end{array}$ & $\begin{array}{r}6,052 \\
15,465 \\
9,247\end{array}$ & $\begin{array}{r}62 \pm 1 \cdot 0 \\
102 \pm 0 \cdot 8 \\
117 \pm 1 \cdot 1\end{array}$ \\
\hline $\begin{array}{l}\text { IVa (Agricultural workers) . } \\
\text { IVb (Others in partly skilled occupations) } \\
\text { Occupation Code } 950 \text { (Social Class V) } \\
\text { All Others in Social Class V } \\
\text { A }\end{array}$ & $\begin{array}{r}21 \\
70 \\
304 \\
41\end{array}$ & $\begin{array}{r}97 \cdot 92 \\
94 \cdot 97 \\
45 \cdot 89 \\
124 \cdot 47\end{array}$ & $\begin{array}{r}21 \pm 4 \cdot 7 \\
74 \pm 8 \cdot 8 \\
662 \pm 38 \cdot 0 \\
33 \pm 5 \cdot 1\end{array}$ & $\begin{array}{r}639 \\
4,048 \\
2,380 \\
3,756\end{array}$ & $\begin{array}{l}1,075 \\
3,870 \\
932 \\
3,370\end{array}$ & $\begin{array}{r}59 \pm 2.4 \\
105 \pm 1 \cdot 6 \\
255 \pm 5 \cdot 2 \\
111 \pm 1 \cdot 8\end{array}$ \\
\hline
\end{tabular}


classes in Northern Ireland to the average of that country; but Table IV shows that the rates for England and Wales are slightly lower than those for Northern Ireland up to about age 50, but that thereafter they are appreciably greater (Figure). Table IV also suggests that for Social Class III the mortality in Northern Ireland is slightly greater than in England and Wales at all ages under 65 years (Figure).

For Social Class IV the S.M.R.s differ widely in the two countries. In each age group the Northern Ireland rates for Social Class IV are lower than those for England and Wales, the difference in the older age groups again being much greater than in the younger (Figure). In order to explain this apparent geographic difference in mortality for Social Class IV, the data were divided into two groups, IVa (agricultural workers) and IVb (others in partly skilled trades). In Northern Ireland, about 50 per cent. of males aged 15 and over in Social Class IV were agricultural workers (IVa) compared with just over 26 per cent. for England and Wales. In both countries the S.M.R.s for agricultural workers (IVa) are much lower than those for the remaining partlyskilled workers (IVb) (Table III). With only one exception, this is true of the age-specific rates shown for each country for Social Classes IVa and IVb in Table V. Moreover, in both Social Classes IVa and $\mathrm{IVb}$, the corresponding age-specific rates are lower in Northern Ireland than in England and Wales in all age groups except 65 and over for Social Class IVa and 25-34 for Social Class IVb. Thus the generally low mortality in Social Class IV in Northern Ireland compared with England and Wales would appear to result from the facts that this class includes relatively more agricultural workers in Northern Ireland than in England and Wales, and that in Northern Ireland agricultural workers have a lower mortality rate in most age groups.

For Social Class V, the rates shown in Table IV and in the Figure (opposite) suggest that males in Northern Ireland have a much higher mortality

TABLE IV

RESPIRATORY TUBERCULOSIS MORTALITY AMONG MALES IN NORTHERN IRELAND AND AND ENGLAND AND WALES (1949-53) BY AGE AND SOCIAL CLASS

AVERAGE ANNUAL NUMBER OF DEATHS PER 100,000 OF THE POPULATION AT STATED AGE GROUP IN YEARS

\begin{tabular}{|c|c|c|c|c|c|c|c|c|c|c|}
\hline \multirow{3}{*}{ Age Group (yrs) } & \multicolumn{10}{|c|}{, Social Class } \\
\hline & \multicolumn{2}{|c|}{$I$ and II } & \multicolumn{2}{|c|}{ III } & \multicolumn{2}{|c|}{ IV } & \multicolumn{2}{|c|}{$\mathbf{V}$} & \multicolumn{2}{|c|}{ IV and $V$} \\
\hline & $\begin{array}{l}\text { Northern } \\
\text { Ireland }\end{array}$ & $\begin{array}{l}\text { England } \\
\text { and Wales }\end{array}$ & $\begin{array}{l}\text { Northern } \\
\text { Ireland }\end{array}$ & $\begin{array}{l}\text { England } \\
\text { and Wales }\end{array}$ & $\begin{array}{l}\text { Northern } \\
\text { Ireland }\end{array}$ & $\begin{array}{l}\text { England } \\
\text { and Wales }\end{array}$ & $\begin{array}{l}\text { Northern } \\
\text { Ireland }\end{array}$ & $\begin{array}{l}\text { England } \\
\text { and Wales }\end{array}$ & $\begin{array}{l}\text { Northern } \\
\text { Ireland }\end{array}$ & $\begin{array}{l}\text { England } \\
\text { and Wales }\end{array}$ \\
\hline $\begin{array}{l}15-19^{*} \\
20-24 \\
25-34 \\
35-44 \\
45-54 \\
55-64 \\
65-69 \\
70+\end{array}$ & $\begin{array}{l}(31) \\
(13) \\
(23) \\
31 \\
39 \\
33 \\
52 \\
25\end{array}$ & $\begin{array}{l}(3) \\
10 \\
17 \\
24 \\
41 \\
58 \\
66 \\
49\end{array}$ & $\begin{array}{c}(10) \\
22 \\
49 \\
52 \\
91 \\
139 \\
(56) \\
58\end{array}$ & $\begin{array}{r}55 \\
17 \\
31 \\
39 \\
64 \\
101 \\
114 \\
69\end{array}$ & $\begin{array}{c}(3) \\
(15) \\
27 \\
(20) \\
40 \\
32 \\
(64) \\
(36)\end{array}$ & $\begin{array}{r}8 \\
21 \\
29 \\
36 \\
59 \\
91 \\
101 \\
63\end{array}$ & $\begin{array}{c}(24) \\
65 \\
79 \\
115 \\
150 \\
192 \\
174 \\
90\end{array}$ & $\begin{array}{r}13 \\
26 \\
45 \\
56 \\
94 \\
129 \\
143 \\
82\end{array}$ & $\begin{array}{r}(11) \\
34 \\
48 \\
65 \\
97 \\
112 \\
114 \\
58\end{array}$ & $\begin{array}{r}10 \\
23 \\
36 \\
44 \\
75 \\
110 \\
123 \\
72\end{array}$ \\
\hline
\end{tabular}

* Age group 16-19 yrs in England and Wales data

TABLE $\mathrm{V}$

RESPIRATORY TUBERCULOSIS MORTALITY AMONG MALES IN NORTHERN IRELAND AND ENGLAND AND WALES (1949-53), BY AGE AND SUB-DIVISIONS OF SOCIAL CLASSES IV AND V

AVERAGE ANNUAL NUMBER OF DEATHS PER 100,000 OF THE POPULATION AT STATED AGE GROUP IN YEARS

\begin{tabular}{|c|c|c|c|c|c|c|c|c|}
\hline \multirow{3}{*}{ Age Group (yrs) } & \multicolumn{4}{|c|}{ Social Class IV } & \multicolumn{4}{|c|}{ Social Class V } \\
\hline & \multicolumn{2}{|c|}{$\begin{array}{l}\text { IVa } \\
\text { (Agricultural Workers) }\end{array}$} & \multicolumn{2}{|c|}{$\begin{array}{c}\text { IVb } \\
\text { (Others in Partly Skilled } \\
\text { Occupations) }\end{array}$} & \multicolumn{2}{|c|}{ Occupation Code 950} & \multicolumn{2}{|c|}{$\begin{array}{l}\text { All Others in } \\
\text { Social Class V }\end{array}$} \\
\hline & $\begin{array}{l}\text { Northern } \\
\text { Ireland }\end{array}$ & $\begin{array}{l}\text { England } \\
\text { and Wales }\end{array}$ & $\begin{array}{l}\text { Northern } \\
\text { Ireland }\end{array}$ & $\begin{array}{l}\text { England } \\
\text { and Wales }\end{array}$ & $\begin{array}{l}\text { Northern } \\
\text { Ireland }\end{array}$ & $\begin{array}{l}\text { England } \\
\text { and Wales }\end{array}$ & $\begin{array}{l}\text { Northern } \\
\text { Ireland }\end{array}$ & $\begin{array}{l}\text { England } \\
\text { and Wales }\end{array}$ \\
\hline $\begin{array}{l}15-19 * \\
20-24 \\
25-34 \\
35-44 \\
45-54 \\
55-64 \\
65-69 \\
70+\end{array}$ & $\begin{array}{l}(3) \\
(13) \\
(12) \\
(5) \\
(15) \\
(16) \\
(57) \\
(71)\end{array}$ & $\begin{array}{r}4 \\
15 \\
21 \\
27 \\
36 \\
47 \\
49 \\
37\end{array}$ & $\begin{array}{l}(4) \\
(20) \\
49 \\
(36) \\
60 \\
(44) \\
(66) \\
(33)\end{array}$ & $\begin{array}{r}11 \\
23 \\
31 \\
38 \\
65 \\
104 \\
125 \\
80\end{array}$ & $\begin{array}{r}(64) \\
199 \\
275 \\
378 \\
462 \\
659 \\
1,724 \\
1,525\end{array}$ & $\begin{array}{c}(15) \\
65 \\
94 \\
95 \\
164 \\
220 \\
258 \\
134\end{array}$ & $\begin{array}{l}(12) \\
(12) \\
(8) \\
(16) \\
(31) \\
(33) \\
(14) \\
(13)\end{array}$ & $\begin{array}{r}12 \\
16 \\
32 \\
46 \\
74 \\
103 \\
110 \\
64\end{array}$ \\
\hline
\end{tabular}

* Age group 16-19 yrs in England and Wales data 
NORTHERN IRELAND

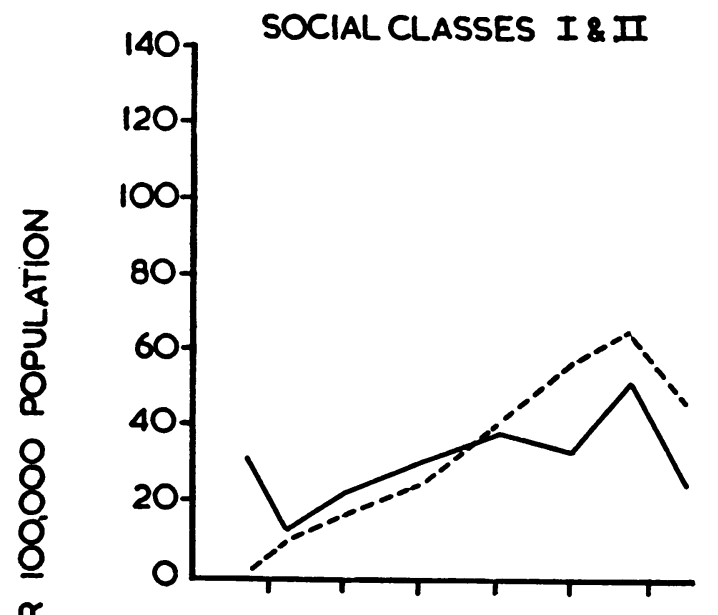

㟧

I 2007 SOCIAL CLASS II

岁

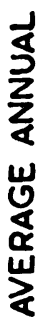

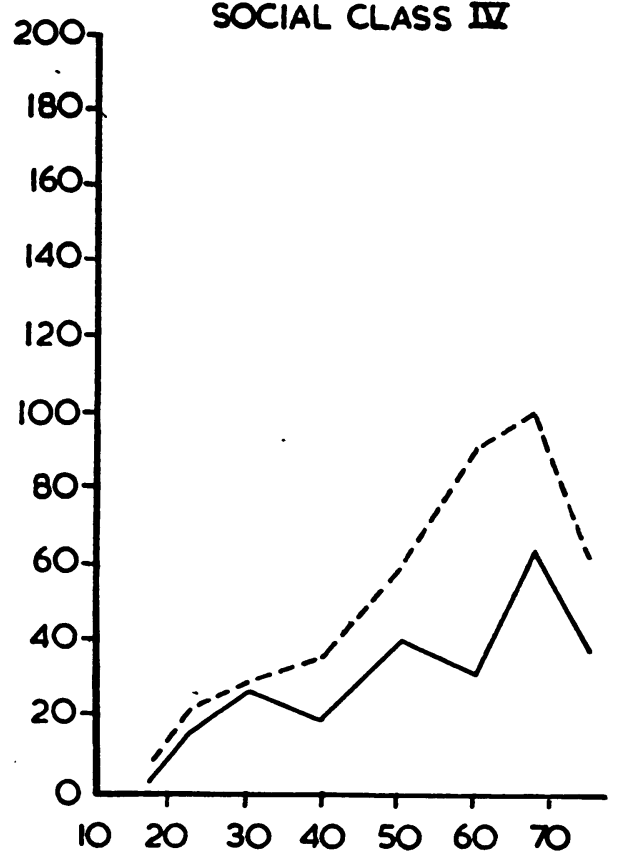

ENGLAND \& WALES
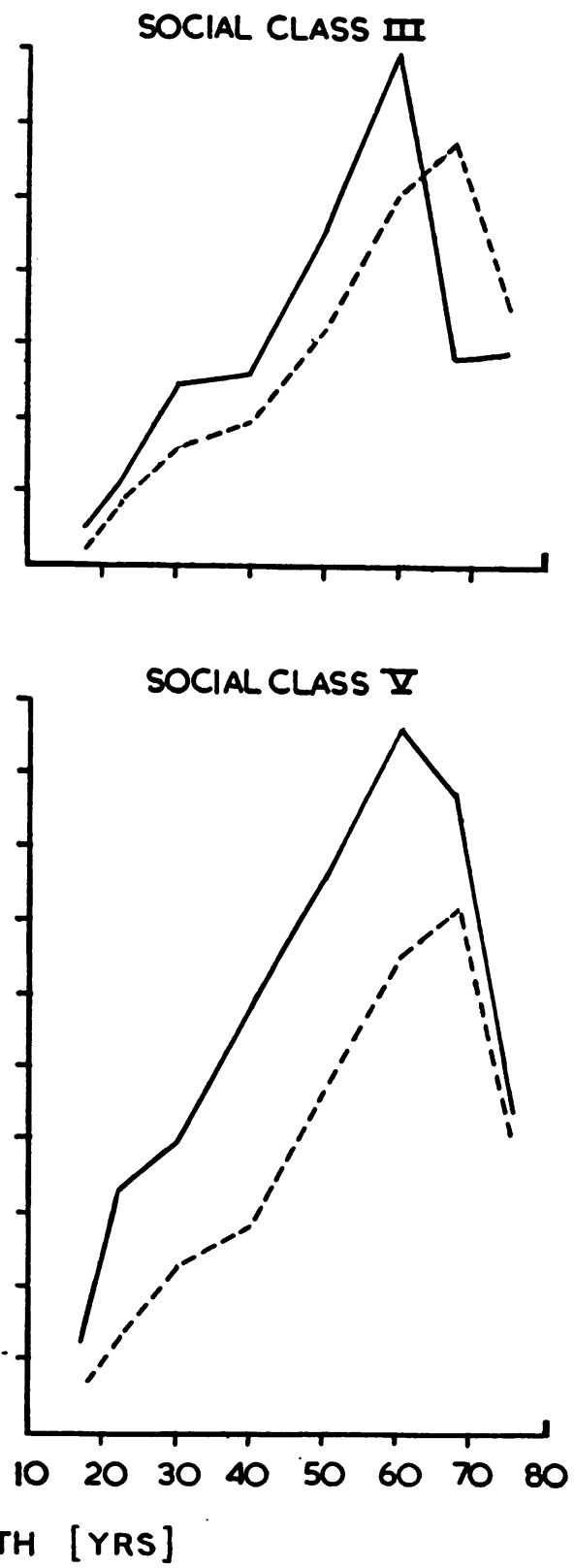

AGE AT DEATH [YRS ]

FIGURE.-Death rates per 100,000 population per annum from respiratory tuberculosis in Northern Ireland and in England and Wales, by age at death and social class. 
from respiratory tuberculosis than those in England and Wales. In the Northern Ireland Social Class V population, 24.4 per cent. of males were coded as 950 (labourer-c"all other industrial and commercial undertakings") (Registrar General for Northern Ireland, 1958) compared with 21.9 per cent. for England and Wales. However, in Northern Ireland it was found that about 88 per cent. of all deaths from respiratory tuberculosis in Social Class V were those of persons whose occupation was coded as 950 compared with about 39 per cent. for England and Wales. This fact and also the fact that the Registrar General for England and Wales (1958b) found that the S.M.R. for this occupation group was 255 per cent. compared with 143 per cent. for Social Class V as a whole could explain the relatively high S.M.R. for Social Class V in Northern Ireland, 203 per cent. compared with 143 per cent. in England and Wales. For Code 950, the Northern Ireland age-specific death rates are three to twelve times larger than the corresponding rates for England and Wales, while in the other occupations of Social Class $V$ the rates in Northern Ireland are consistently lower than the corresponding rates in England and Wales.

The obvious explanation of these differences is that "labcurers" (Code 950) in Northern Ireland do, in fact. experience a much heavier mortality from respiratory tuberculosis than labourers in England and Wales, while others in Social Class V and agricultural workers in Social Class IV under age 65 experience a somewhat lower mortality in Northern Ireland than corresponding groups in England and Wales. It has been suggested that these differences in the mortality of labourers (Code 950) may be attributable to some social factor such as a persistently higher level of unemployment in Northern Ireland. Unfortunately the published data on unemployment is not available in sufficient detail to prove or disp:ove this hypothesis.

An alternative explanation for the high mortality in labourers (Code 950) might be that classification of unskilled and partly-skilled jobs at death registration is less exact in Northern Ireland than in England and Wales. Thus some of the deaths at present classified in the labourers' group (Code 950) in Northern Ireland might, in fact, be more appropriately classified in other sub-groups of Classes IV and $\mathrm{V}$.

However, it is impossible to decide which of these explanations is the more likely, or what part each plays in producing the differences observed in the rates. Therefore it seems wise to make comparisons between the two countries for a combined group of Social Classes IV and V. The S.M.R.s for this combined group are shown in Table III, and the age-specific rates in Table IV for each of the two countries. Up to age 65 the rates in Northern Ireland are greater than those in England and Wales, but thereafter the reverse is true.

\section{SUMMARY}

In Northern Ireland the mortality from respiratory tuberculosis for males aged 15 and over is similar in Social Classes I and II combined and Social Class IV. Social Class III has approximately double this mortality, while Social Class V has roughly twice the mortality of Social Class III. It is possible that because of poor definition of labouring occupations at death registration, these S.M.R.s should, in fact, be lower for Social Class V and higher for Social Class IV. It seems safer, therefore, to express the social class distribution of respiratory tuberculosis mortality for males in Northern Ireland in terms of three social class groups formed by I and II combined, III alone, and IV and V combined. The S.M.R.s for these groups are then 48,115 , and 120 per cent. respectively. However, the trend implied by these S.M.R.s is not consistent throughout the age groups.

Comparison of data for Northern Ireland witlo those for England and Wales reveals several ime portant differences in this aspect of mortality. If Social Class IV the Northern Ireland males had lower mortality at all ages, the difference in the two areas being least in the younger age groups. This result may be partly explained by the facts that the proportion of agricultural workers in Northern Ireland is about double that in England and Wales, and that such workers had a lower mortality than the remainder of Social Class IV in the two countries. Social Class V mortality at all ages was found to be greater in Northern Ireland than in England and Wales and this may be explained either by a real difference in mortality or by differences in the precision of recording occupations on death registration certificates.

When Social Classes IV and V are combined, the Northern Ireland rates are the higher until about age 60 , and thereafter the England and Wales rates are the higher.

I am indebted to Mr. L. C. Mulligan, the Registrar General for Northern Ireland, for granting me access to the information about Northern Ireland necessary for this report, and to Dr. W. P. D. Logan for supplying me with unpublished information about occupation Code 950 in England and Wales. My thanks are also due to Mrs. Dorothy Hutton for typing the manuscript and to Miss E. E. Thornbury for preparing the figures. 
REFERENCES

General Register Office (1956). "Census, 1951. Classification of Occupations." H.M.S.O., London.

Registrar General for England and Wales (1958a). "Decennial Supplement, England and Wales, 1951." Occupational Mortality,

- for England and Wales (1958b). "Decennial Supplement, England and Wales, 1951." Occupational Mortality, Part II, vol.

2: Tables. H.M.S.O., London.
Registrar General for Northern Ireland (1955). "Census of Population of Northern Ireland, 1951." General Report. H.M.S.O., Belfast. of Northern Ireland, 1951." General Report. H.M.S.O., Bel
for Northern Ireland (1958). Personal communication. 